\title{
Fruit Plants Species along Corridor in Kopendukuh Village as a Resource for Rural Tourism Development
}

\author{
Widya Kristiyanti Putri, Abu Naim*, Hendra Setiawan \\ Master Program of Biology, Faculty of Mathematics and Natural Sciences, University of Brawijaya, Malang, Indonesia
}

\begin{abstract}
This research aims to identify fruit plants species which is potential for tourism attraction, spatially describes fruit plants distribution and identify local people's response for fruit plants as tourims attraction in Kopendukuh village, Banyuwangi. Survey was done along the villages corridors. The fruit plant species along corridors was identified and mapped using GPS. Furthermore, semi-structural interview was used to gain informations of local people response about fruit plants as tourism attraction. There were about 18 species and 162 individuals were found along corridor of Kopendukuh village. Fruit plants always found in local home gardens along rural corridor. Local peoples argue that fruit planst s important for numerous purposes. Local people support tourism development in rural area which based on the fruit plants richness (i.e. agrotourism).
\end{abstract}

Keywords: fruit plants, mapping, corridor, rural tourism.

\section{INTRODUCTION}

Rural tourism is a kind of tourism which has characteristics that signify a rural area; including small settlements, low population densities, agrarian-based economies, and traditional societies [1]. In rural tourism, there are several interesting aspect to become tourism attraction, such as culture, natural landscape, specific flora and fauna which life in their area, etc. One of potential resource for tourism attraction is fruit plants field [2].

Fruit plants in Indonesia have a unique characteristic because it affected by season. In harvest time, fruits field became interesting place to visit because visitors can eat fruit directly from the field. They even can teach their children about fruit plants. Thus, fruit plants as food producer can be used as tourism attraction base on agroecotourism. Tourism attraction base on agroecotourism have some function, not only attraction for tourist but also for conservation tools [3]. Besides that agroecotourism can used as additional income for local people [4].

Export commodity of agriculture was dominated by plantation sector that reach 133.37 billion dollars in 2010 to 2013. Especially in fruit was dominated by mango with growth rate reach $29.56 \%$ while the lowest was mangosteen with growth rate $9.49 \%$ per year [5]. Fruit plants can be divided in two groups, wild fruit plants and

\footnotetext{
* Correspondence address:

Abu Naim

Email : naimrahmatullah87@gmail.com

Address : Master Program of Biology, University of Brawijaya, Jl. Veteran Malang, 65145
}

cultivar fruit plants. Cultivar fruit plants which cultivated in local people field have many variations, consist of native fruit plants and exotic fruit plants.

Banyuwangi is an area with abundant natural tourism attraction. Fruit is important product to support tourism, especially in agrotourism development [2]. Most of fruit plants in local community field in corridor of the village to ljen Carter is common fruit plant in Indonesia, e.g. manggo (Mangifera indica L.), rambutan (Nephelium lappaecum L.), manggosteen (Garcinia mangostana L.), durian (Durio zibethinus Murray), water apple (Syzygium aquea (Burm. f) Alston) and guava (Psidium guajava L.) etc. [6].

Kopendukuh village is very potential for tourism object which base on agroecotourism, using their fruit plants as the attractions. Besides they can make additional income, they can conserve their fruit plants especially their native fruit plants.

Almost every people's field of Kopendukuh have their own fruit plants. These fruit plants are very interesting for tourists who pass their village to visit Ijen Carter. Objectives of this reserch are to identify fruit plants species in Kopendukuh village which is potential for tourism attraction, mapping distribution of fruit plants in Kopendukuh village and to know about the response of local people for fruit plants as tourims attraction.

\section{MATERIALS AND METHODS}

The study area was located in the Kopendukuh village, Glagah District, Banyuwangi on coordinates of $08^{\circ} 09^{\prime} 47.7^{\prime \prime} \mathrm{S}, 114^{\circ} 17^{\prime} 36,6^{\prime \prime} \mathrm{E}$ (Fig. 1). 


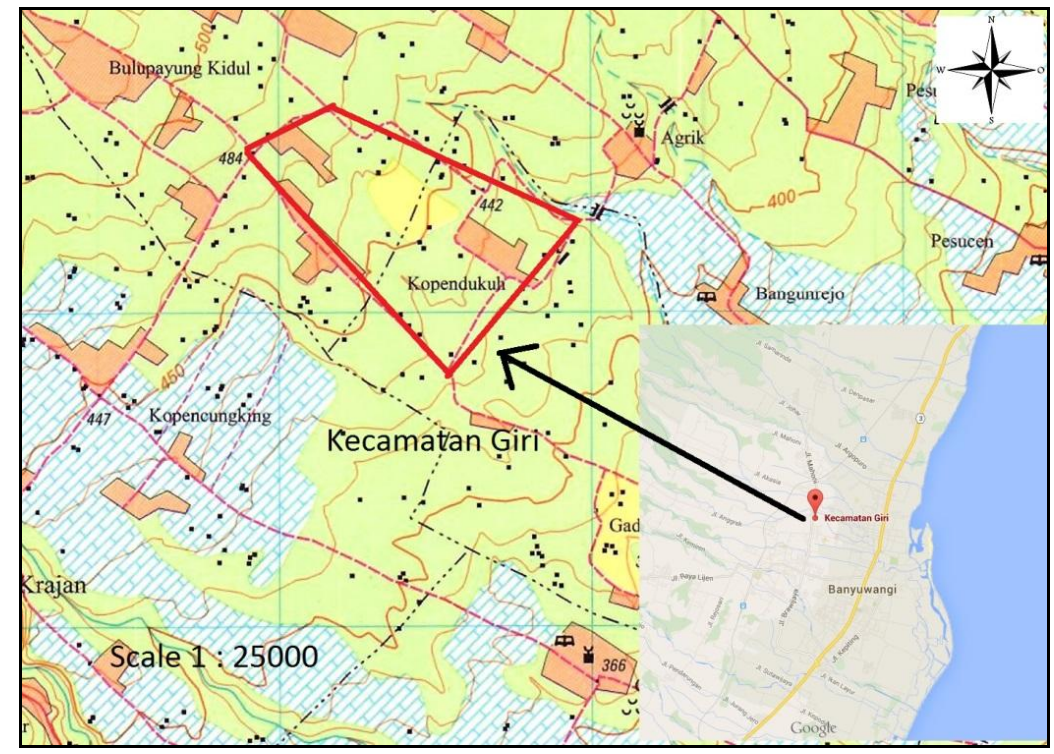

Figure 1. Map of Kopendukuh village

It is a corridor which conected to a famous tourism object, Ijen Crater. Most people in Kopendukuh village are farmers, who representat people from Banyuwangi Regency [7].The data of fruit plants was obtained through direct survey method, plant mapping, and plant identification. Data collection was carried out in November $15^{\text {th }}$, 2014.

Method that use in sampling was researcher appoints key informants then they will recommend some other informants as resource. The informants were the local people who lived for long time in Kopendukuh village and have fruit fields. Survey conducted in semi structural interview was expected to be closer to the people which include some information about locations of plants, type of plants, and experience in fruit plant treatment.

The spatial distribution was mapped by GPS. The coverage survey are in range of Fruit Crops discover at a distance of $10 \mathrm{~m}$ along right and left side corridor of Kopendukuh village. Coordinate data that was obtained by plotting on a map use Quantum GIS (QGIS) 2.4 .0 (Chugiak) [8] and overlay with countour map layer from ASTER image GDEMV2 (product of MET land NASA). It is also overlay with a base map of the study area conditions to perform a digitized map with geographical map of Indonesia [9].Coordinate data that has been plotted processed further using geoprocessing tools of QGIS. Buffers features are used to determinethe distribution of a species and intersect feature was used to determine the distribution of occupied habitat which is shared between each species of fruit crops. The results of the analysis are then overlaid with other layers to obtain the final result of the zoning map of fruit trees along the corridor in Kopendukuh village.

Plant identification was conducted by direct observation. The local and scientific name of plants consider with the growth place was noted. Plant age as the indicator of maturity could become consideration of restoration project. The older plants mean they reserved the area for long time and useful for local people while the younger plants mean they are introduction species or they had been damage and replanted. Measurement of plant age used diameter at breast height $(\mathrm{DBH})$ method. Then the plant can be classified as seedling, sapling, small tree, tree or shrub (Table 1).

Table 1. Age classification of fruit plants

\begin{tabular}{ll}
\hline Plant classification & Definition \\
\hline Seedling & DBH $<7.5 \mathrm{~cm}$ \\
Saplings/Poles & DBH $7.5-24 \mathrm{~cm}$ \\
Small tree & DBH $25-37 \mathrm{~cm}$ \\
Tree & DBH $>38 \mathrm{~cm}$ \\
Shrubs & - \\
\hline Source: Keane [10] &
\end{tabular}

Source: Keane [10]

\section{RESULTS AND DISCUSSION}

The distribution of fruit plants concentrated to the settlement along rural corridors. Basically, a home garden is loaded in term of fruit species (Fig. 2). This rural road is an alternative track for tourists who want to visit ljen Crater which located at the west side of this village or for special destination to enjoy the variation fruits. 
Fruit plants can be found along the corridor in Kopendukuh Village. Local people plant it in their yard because it has a lot of function, such as its fruits are edible, its canopy can be use as shade, and its branch can be used as fire wood. Based on observation in fields, local people also sold their fruits in local markets. Scholars point out that the functions of fruits plants for local people yard are numerous, encompasess plants for commercial used, consumption, shade plant, and fire wood $[2,11]$.

Based on the interview, local community has other purposes in growing the fruit plants in home garden, i.e. prevent flooding in rainy season and maintain ground water supply in a dry season. Another function of fruit plant for local people is stabilization of environment quality as land erosion control, biodiversity and reserves carbon. Along corridor in Kopendukuh village there were 18 fruit plants species. These species were Salacca zalacca, Nephelium lappaceum, Musa x paradisiaca, Carica papaya, Artocarpus heterophyllus, Ananas bracteatus, Passiflora edulis, Garcinia mangostana, Lansium parasiticum, Chrysophyllum cainito, Cocos nucifera, Citrus $x$ sinensis, Psidium guajava, Syzygium aquea, Durio zibethinus, Theobroma cacao, Hylocereus costaricensis, and Persea americana.

There were 10 plots with each plot consists of 7 to 12 species of fruits (Fig. 3). Total number of individual fruit plants which found was 162 (Fig. 4). All of these species are common fruits and favor by local community. Most of them can be found in courtyard and backyard of resident's home along the corridor in Kopendukuhvillage. Many fruit plants were found in the corridor Kopendukuh village because local people still have extensive homegarden around the house. We still found orchards which deliberately made by the local people as a form of economic investment. Ko-pendukuh village is part of Giri Sub-district and smallest population density (29.681 people) in Banyuwangi. The average population density is 279 people per $\mathrm{km}^{2}$ [12]. Existence of home garden in corridor was result of low population density in the region.

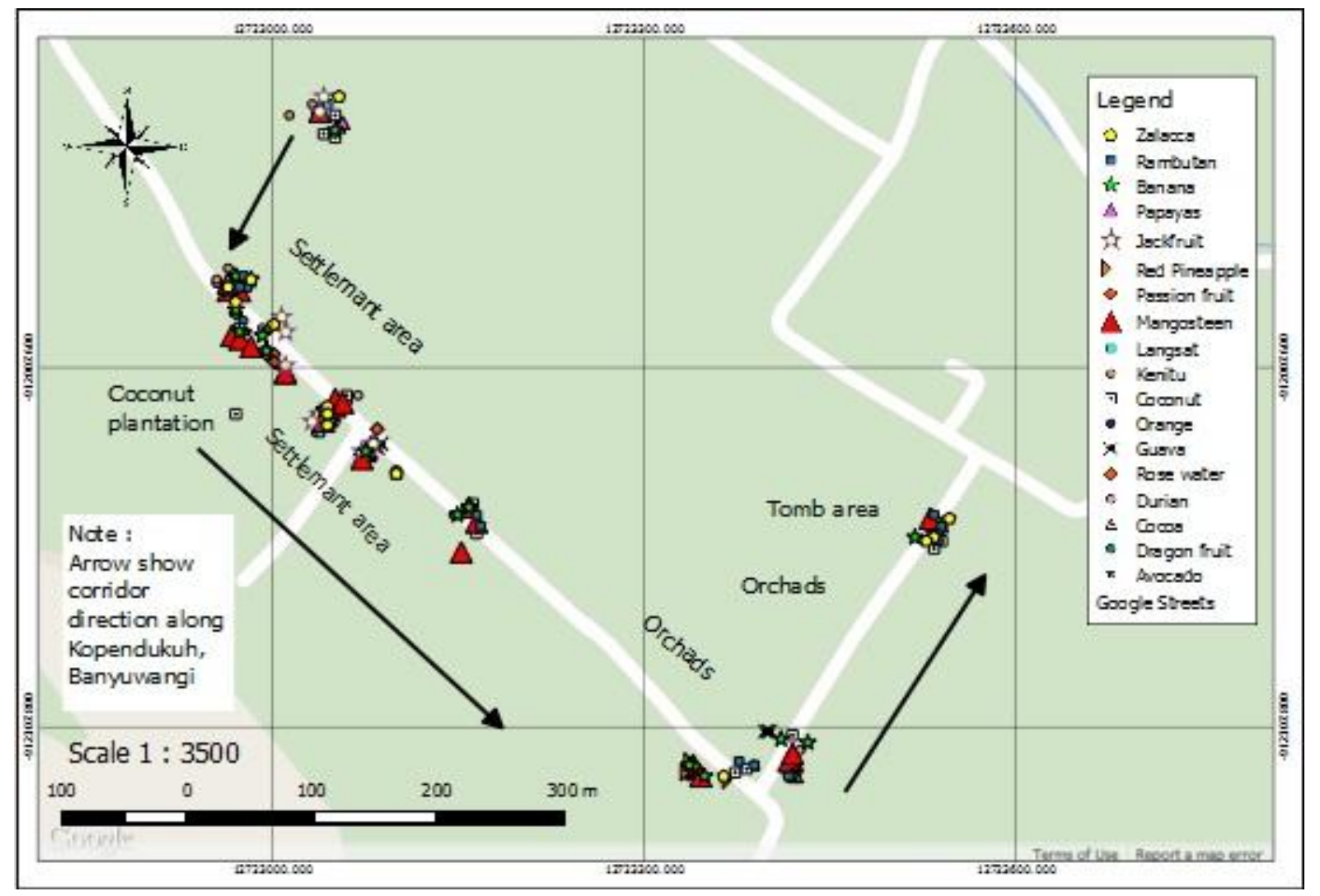

Figure 2. Map of fruit plant's distribution in Kopendukuh 

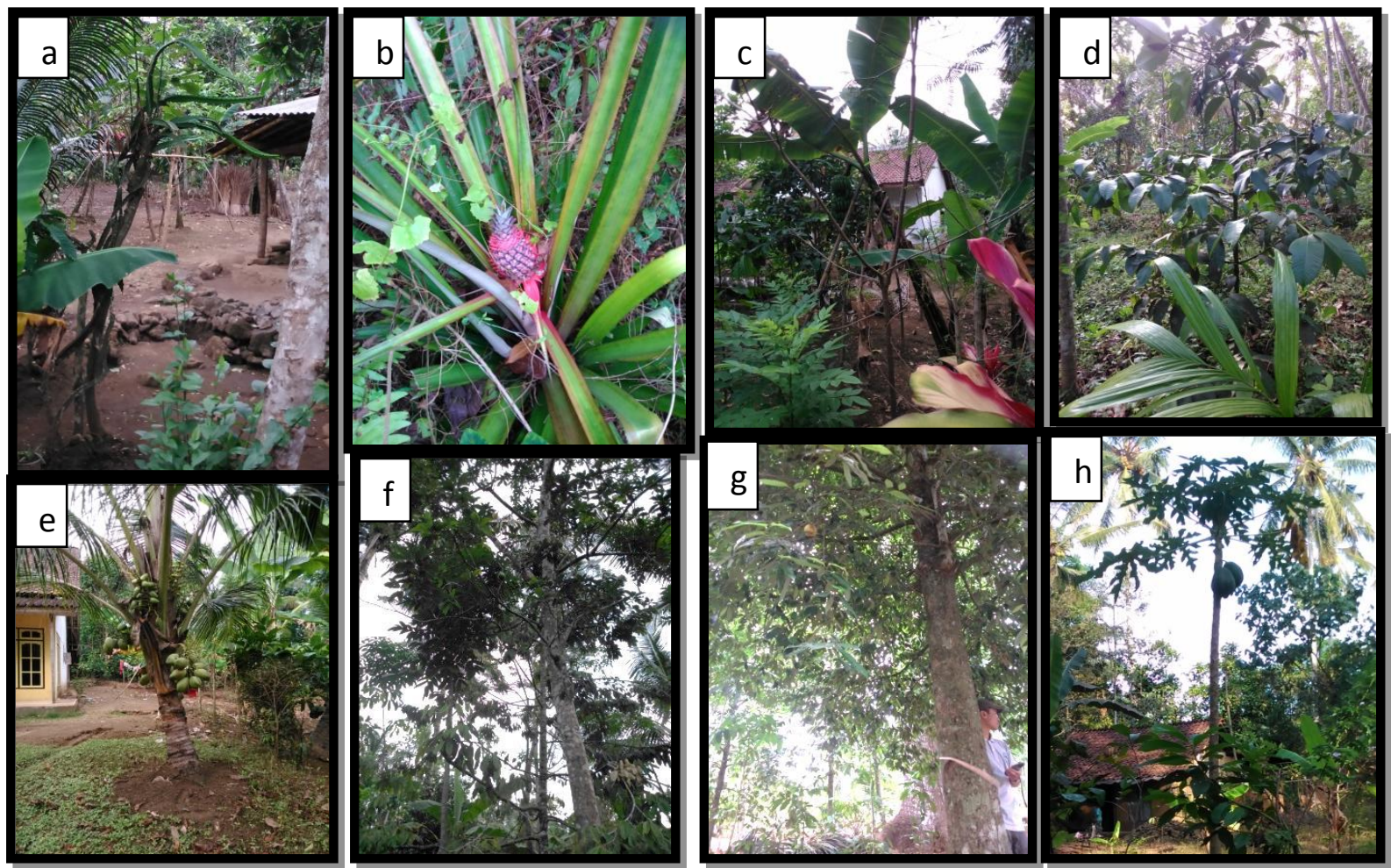

Figure 3. Fruit plants along corridor in Kopendukuh village

( $a=$ Dragon fruit, $b=$ Pinneaple, $c=$ Banana, $d=$ Mangosteen, $e=$ Coconut, $f=$ Durian, $g=$ Kenitu, $h=$ Papaya)

Distribution of fruit plant along the corridor in the Kopendukuh village dominated by seeded fruit plant such as coconut (C. nucifera), mangosteen (G. mangostana), durian (D. zibethinus), papaya (C. papaya) and zalacca ( $S$. zalacca) (Fig. 2). Not only have high economic value, the fruit plants are suitable with the topography. The topographic is generally highland and has an average slope rate of $40^{\circ}$ with an average high rainfall. This condition is very suitable for the growth and development of the fruit crops. Based on DBH measurement, fruit plants that were found along the corridor in Kopendukuh Village categorized as seedlings and trees (Fig. 5). Observation in 10 sites along this corridor got 47 kinds of regenerations and 46 trees. Regeneration was dominated by mangosteen while tree was dominated by coconut.

The highest amount of coconut as tree meaning that coconut was cultivated in this area for long time. Meanwhile, number of mangosteen in sapling showed that this plant cultivated by Kopendukuh local people recently. Coconut and mangosteen have potential as tourism attraction and main commodity of Banyuwangi, East Java. Mangosteen and coconut have been exported routine to Japan and
Thailand. Mangosteen could be exported in 2 containers or equal to 40 ton while coconut export to Thailand in 30 containers per week ( 1 container=20 ton). These exports have increased in last years.

Based on these maturities, development of fruit plant as tourism attraction in recent day was focused in coconut because it can be used directly, but in future it will focus in mangosteen. According to interview with 15 local people, we found that they gladly support village development for tourism site such as agritourism fruit plants. There were productive fruit plants in their fieldand backyard (Fig. 6). These fruit were used for their meal, medicine, or commercial need.

As seen in figure 5, mangosteen was grow in almost all field after coconut. This because in 1998 the government program was to make mangosteen as main commodity for export need. We gained information from local people that they can harvest their fruits all years. They never have serious problems such as pests, gulma or less of water like in East Java's field problems generally. They keep their field with natural ways thus safe for their environment. Local people didn't use fertilizer or only use compos fertilizer and never use pesticide (Fig. 7). This method is suitable for one of ecotourism objectives. 


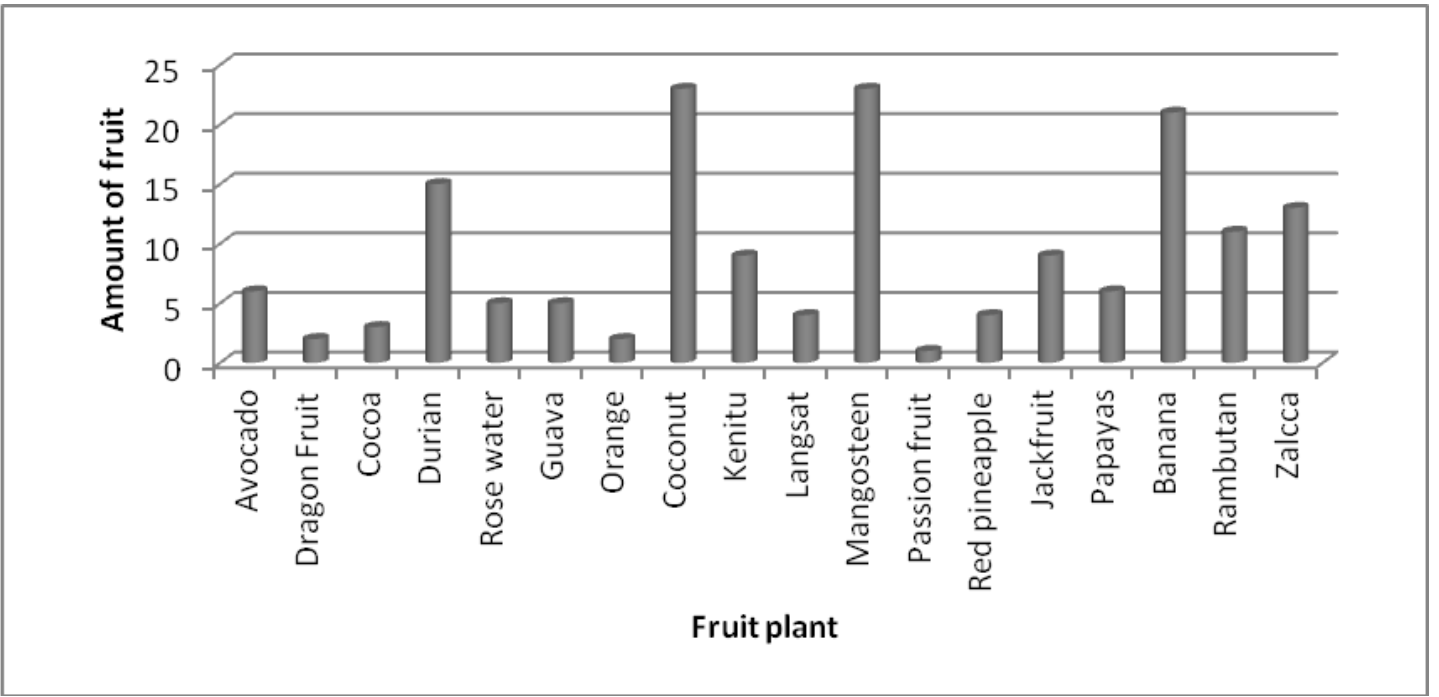

Figure 4. Number of fruit plants found in home gardens along rural corridors

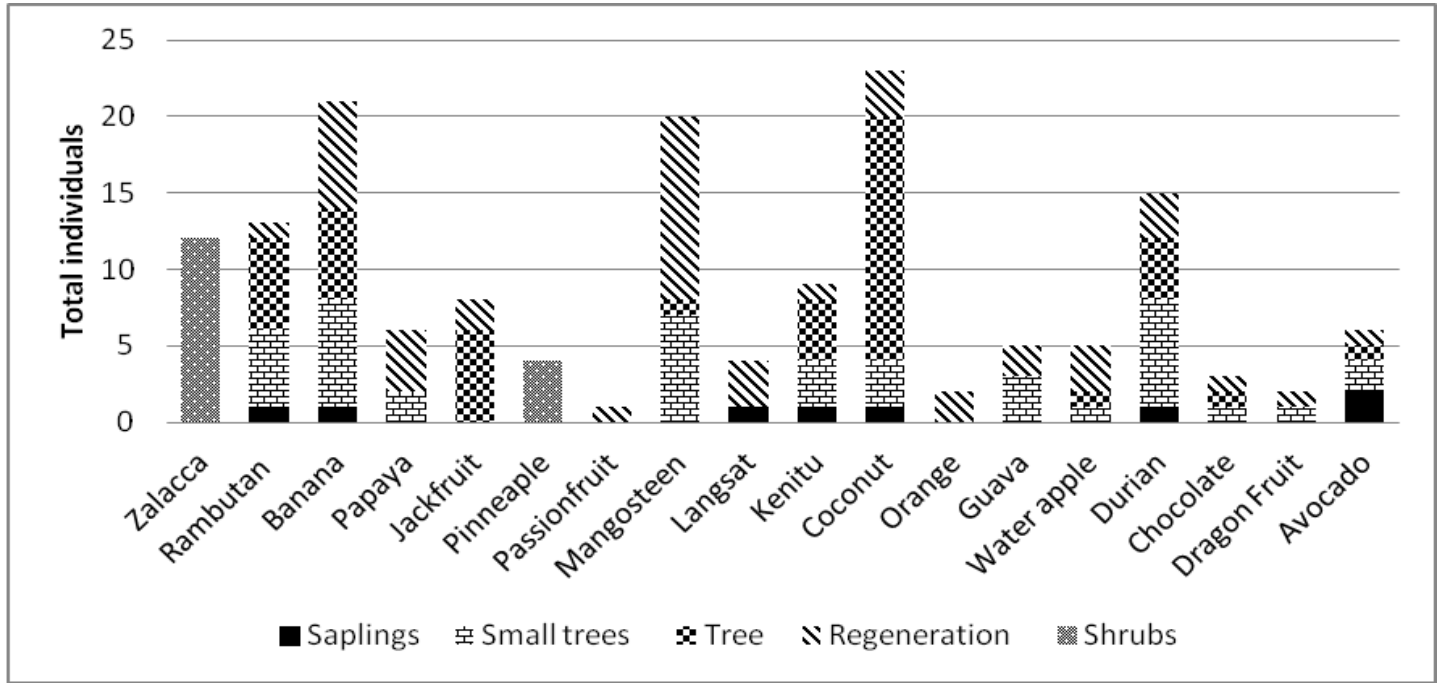

Figure 5. Fruit plants clasification based on DBH in Kopendukuh Village

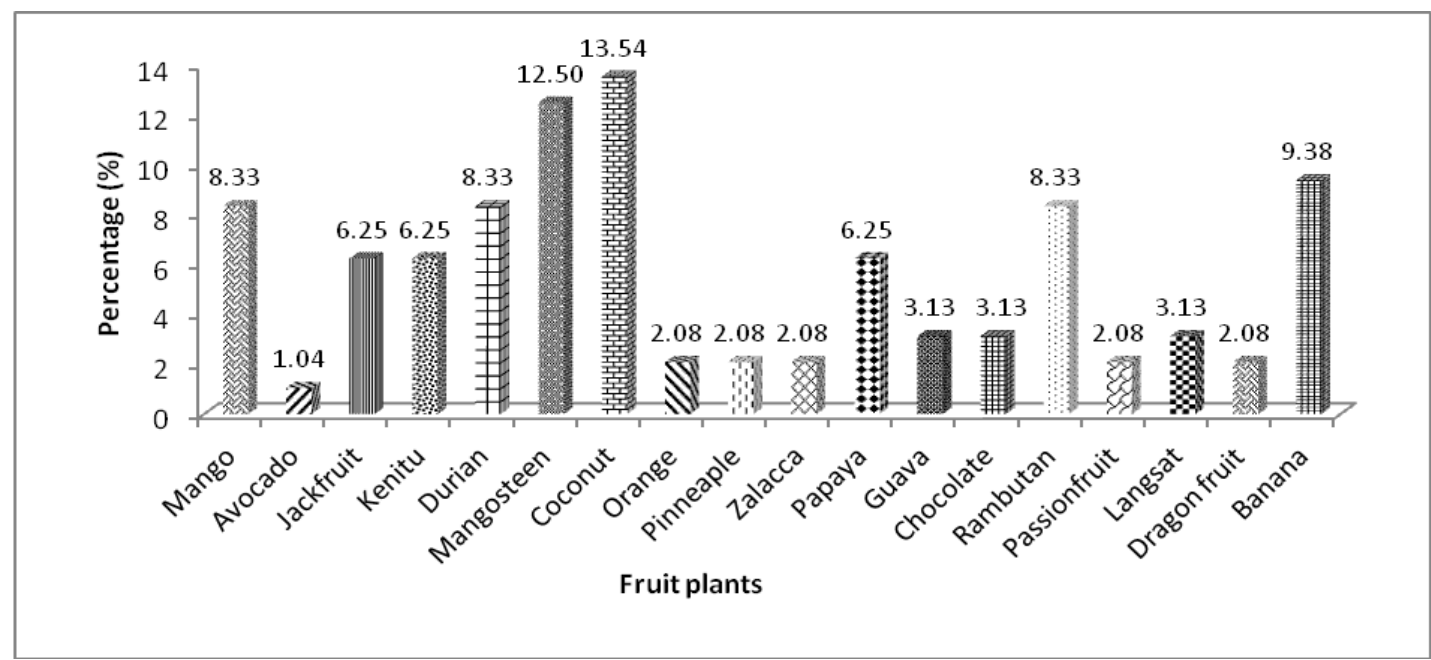

Figure 6. Percentage of fruitplants in respondents' field and backyard $(n=15)$ 


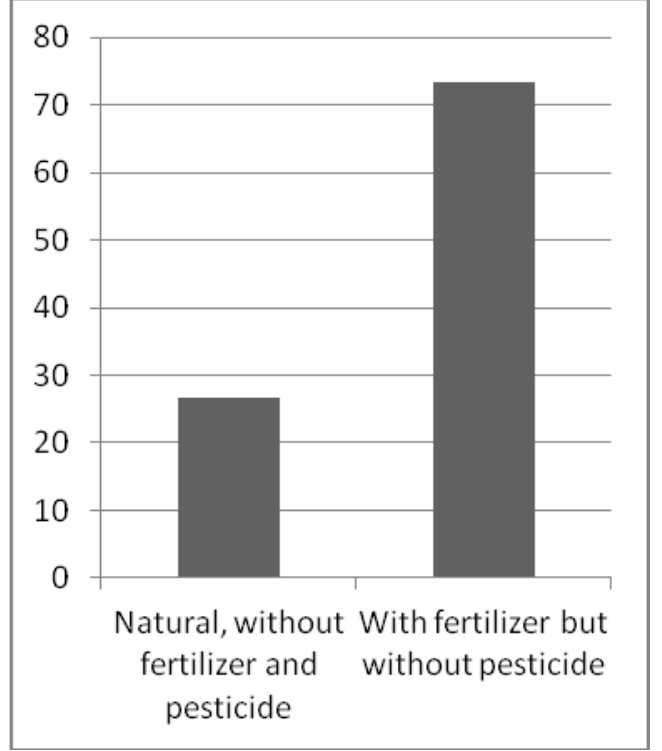

Figure 7. Diagram of treatment method for fruit plant in respondents' field and backyard $(n=15)$

\section{CONCLUSION}

Fruit plants that found in along corridor Kopendukuh village were zalacca, rambutan, banana, papaya, jackfruit, pineapple, passion fruit, mangosteen, langsat, kenitu, coconut, orange, guava, water apple, durian, chocolate, dragon fruit and avocado. Local people gave positive responses for fruit plants as tourims attraction. Total of 18 species of fruit plants was found in their field and along corridor were treated with natural ways, e.g. without fertilizer and pesticide. This research concluded that plant fruits species along corridor in Kopendukuh village could become resource for rural tourism development.

\section{REFERENCES}

[1] Okech, R., M. Haghiri, and B.P. George. 2012. Rural tourism as a sustainable development alternative: an analysis with special reference to Luanda, Kenya. Cultur 6 (3). www.uesc.br/revistas/Culturaeturismo.

[2] Hakim, L. 2014. Ethnobotany of home garden: food security, health and agrotourism. Selaras Publisher, Malang.

[3] Blangy, S., and H. Mehta. 2006. Ecotourism and ecological restoration. Journal for Nature Conservation 14, 233-236.

[4] Stronza, A. 2007. The economic promise of ecotourism for conservation. Journal of ECO Tourism 6 (3). DOI: 10.2167/joe177.0.

[5] Ministry of Agriculture, 2014. Statistic of exsport-import on agriculture commodity
2001-2013. Jurnal Statistik Ekspor Impor Komoditas Pertanian. ISSN: 2337-9578. Directorate General of Processing and Marketing of Agricultural Products. Ministry of Agriculture.

[6] Zakiyah, Z., S. Indriyani, and L. Hakim. 2013. Pemetaan Sebarandan Karakter Populasi Tanaman Buah di Sepanjang Koridor Jalur Wisata desa Kemiren, Tamansuruh, Dan Kampunganyar, Banyuwangi Regency. Journal of Indonesian Tourism and Development Studies 1 (2), 46-51.

[7] Central Statistic Bureau of Banyuwangi. 2014. Population. http://banyuwangikab. bps.go.id/. Accessed November 10 ${ }^{\text {th }}, 2014$.

[8] Quantum GIS Development Team. 2003. Quantum GIS Geographic Information System. Open Source Geospatial Foundation Project. http://qgis.osgeo.org

[9] Bakosurtanal (Office of National Coordination and Mapping). 2000. Digital geographic map of Indonesia. Sheet 1607444. First Edition.

[10] Keane, R. E., 2006. Tree Data (TD) sampling method. USDA Forest Service Gen. Tech. Rep. RMRS-GTR-164-CD. Accessed November $10^{\text {th }}, 2014$.

[11] Purnomosidhi, P., S. Roshetko, J.S. Mulawarman. 2002. Propagation and cultivation of fruits, specifically on durio, mango, orange, Melinjo, and Sawo. Bogor: ICRAF.

[12] Central Statistic Bureau of Banyuwangi. 2012. White book of sanitation in Banyuwangi Regency. Accessed January $13^{\text {th }}$, 2014.

[13] Lukaszkiewicz, J. and M. Kosmala. 2008. Determining the age of streetside trees with diameterat breast height-based Multifactorial Model. Arboriculture and Urban Forestry 34(3),137-143. 